\title{
PENGARUH RETURN ON ASSETS, KOMITE AUDIT DAN LEVERAGE TERHADAP PENGHINDARAN PAJAK (TAX AVOIDANCE) (Studi pada Perusahaan Jasa Sub Sektor Perdagangan Besar yang Terdaftar di Bursa Efek Indonesia Periode 2012 - 2016)
}

\author{
Kimsen $^{1}$ \\ Akuntansi, Fakultas Ekonomi dan Bisnis, UniversitasMuhammadiyah Tangerang \\ *kimsensinungan@yahoo.co.id ${ }^{1}$ \\ Arry Eksandy ${ }^{2}$ \\ Akuntansi, Fakultas Ekonomi dan Bisnis, UniversitasMuhammadiyah Tangerang \\ *arry_eksandy@umt.ac.id ${ }^{2}$ \\ Yuni Erisa ${ }^{3}$ \\ Akuntansi, Fakultas Ekonomi dan Bisnis, Universitas Muhammadiyah Tangerang \\ *yunierisa@yahoo.com ${ }^{3}$
}

\begin{abstract}
Tax avoidance is a tax savings actionsthat are still in the realm of tax law (lawful fashion). Return on assets, audit committees, and leverage are used as independent variables were estimated impact ontax avoidance as the dependent variable and proxied through Effective Tax Rate (ETR). This research was conducted on manufacturing firms in Indonesia Stock Exchange (IDX) 2012-2016. Data obtained by accessing the Indonesia Stock Exchange'swebsite. The samples in this study used purposive sampling technique in order to get a sample size of 6 companies and the number of observations is 35 companies. Data in this study were analyzed with panel data analysis techniques. The results of this study indicate that the return on assets and audit committee size has a negative effect on tax avoidance, while the leverage has no effect on tax avoidance.
\end{abstract}

Keywords : Tax Avoidance, Return On Assets, Audit Committee, And Leverage. 


\section{PENDAHULUAN}

Dalam upaya mensejahterakan Negara dalam berbagai aspek, pemerintah Indonesia pastinya membutuhkan dana yang sangat besar. Terkait dengan dana yang dibutuhkan, sektor penerimaan terbesar yang untuk membiayai perekonomian negara Indonesia berasal dari sektor perpajakan. Pajak itu sendiri secara umum diartikan sebagai pungutan yang dilakukan oleh pemerintah berdasarkan oleh peraturan perundang-undangan yang hasilnya digunakan untuk pembiayaan pengeluaran umum pemerintah. Dalam praktik pelaksanaan pajak itu sendiri, salah satu pihak yang memberikan kontribusi besar dalam sektor penerimaan pajak adalah perusahaan atau pemilik usaha. Namun, tujuan dari pemerintah untuk memaksimalkan penerimaan dari sektor perpajakan bertentangan dengan tujuan dari perusahaan sebagai wajib pajak. Sesuai dengan asumsi bahwa pajak dianggap sebagai beban, maka timbul keinginan untuk mengurangi pajak tersebut sama halnya seperti keinginan untuk mengurangi bebanbeban yang lain (Mangoting, 1999 dalam Maharani, 2015). Anggapan inilah yang membuat wajib pajak melakukan usaha untuk mengatur jumlah pajak yang harus dibayar. Ketidaksenangan membayar pajak ini juga dipengaruhi oleh sifat pajak yang tidak memberikan kontra prestasi secara langsung bagi pembayar pajak. Perusahaan berusaha mengefisiensikan beban pajaknya sehingga dapat memaksimalkan laba perusahaan, karena semakin besar beban pajak yang dibayar maka laba perusahaan akan semakin berkurang. Salah satu usaha yang dilakukan perusahaan untuk mencapai laba yang diharapkan adalah melakukan upaya mengurangi jumlah pajak yang harus dibayar. Dengan kata lain timbul konsekuensi tindakan manajerial dalam perusahaan, khususnya tindakan manajerial yang dirancang untuk meminimalkan kewajiban pajak perusahaan. Strategi perusahaan untuk mengurangi atau menghindari pajak memangdapat menguntungkan pemegang saham tetapi hal itu mengorbankan masyarakat mengingat bahwa pajak digunakan sebagian untuk infrastruktur pemerintah dan program-program sosial (Sikka, 2010 dalam Maharani, 2015). Menurut Budiman dan Setiyono (2012), Persoalan penghindaran pajak merupakan persoalan yang rumit dan unik. Di satu sisi diperbolehkan akan tetapi disisi lain penghindaran pajak tidak diinginkan. Di indonesia telah dibuat berbagai aturan guna mencegah adanya penghindaran pajak. Salah satunya adalah terkait transfer pricing, yaitu tentang prinsip kewajaran dan kelaziman dalam transaksi antara wajib pajak dengan pihak yang mempunyai hubungan yang istimewa (Perdirjen No. PER43/PJ/2010, 2010). Aktivitas penghindaran pajak merupakan suatu transaksi yang dilakukan oleh perusahaan untuk meminimalkan beban pajak dengan memanfaatkan 
ketentuan perpajakan suatu negara sehingga transaksi tersebut dapat dikatakan legal karena tidak melanggar ketentuan perpajakan (Kanagaretnam, et al. 2014 dalam Maharani, 2015). Salah satu bentuk pengawasan bagi tindakan manajerial dalam bidang pajak adalah membentuk tata kelola perusahaan yang baik, termasuk didalamnya pengawasan yang dilakukan oleh salah satu komponen Corporate Governance yaitu komite audit (Tandean, 2012 dalam Nurindah 2013).

\section{Rumusan Masalah}

Rumusan masalah yang akan dibahas dalam penelitian ini adalah sebagai berikut:
1. Apakah Return On Assets berpengaruh terhadap penghindaran pajak?
2. Apakah Komite Audit berpengaruh terhadap penghindaran pajak ?
3. Apakah Leverage berpengaruh terhadap penghindaran pajak?

\section{Tujuan penelian}

Tujuan penelitian ini adalah sebagai berikut :

1. Untuk mengetahui pengaruh return on assets terhadap penghindaran pajak.

2. Untuk mengetahui pengaruh komite audit terhadap penghindaran pajak.

3. Untuk mengetahui pengaruh leverage terhadap penghindaran pajak?

\section{KAJIAN TEORITIS DAN HIPOTESIS PENELITIAN \\ Kajian Teoritis}

1. Teori Keagenan (Agency theory)

Agency theory menyatakan bahwa adanya hubungan kerja antara pihak yang memberi wewenang (principal) yaitu investor dengan pihak yang menerima wewenang (agensi) yaitu manajer, dalam bentuk kontrak kerja sama yang disebut "nexus of contract". Jensen and Meckling (1976), menyatakan manajer sebagai agen tidak selalu bertindak sesuai kepentingan pemegang saham sebagai principal, agar manajer bertindak sesuai kepentingan pemegang saham, manajer diberi insentif yang cukup dan dengan mengeluarkan biaya monitoring untuk membatasi penyimpangan oleh manajer. Dalam teori keagenan, masalah keagenan timbul karena diasumsikan bahwa manajer bertindak self interest. Untuk itu muncul biayabiaya keagenan untuk mengatasi masalah ini. Perbedaan kepentingan antara principal dan agen inilah yang disebut dengan agency problems yang dapat juga disebabkan karna adanya asimetri informasi .

\section{Penghindaran Pajak (Tax Avoidance)}

Penghindaran pajak adalah usaha pengurangan pajak, namun tetap mematuhi ketentuan peraturan perpajakan seperti memanfaatkan pengecualian dan potongan yang diperkenankan maupun menunda pajak yang belum diatur dalam 
peraturan perpajakan yang berlaku (Heru, 1997 dalam Budiman dan Sutiyono 2012).

\section{Return On Asset (ROA)}

Return On Asset (ROA) merupakan salah satu indikator keberhasilan perusahaan untuk menghasilkan laba sehingga semakin tinggi profitabilitas maka semakin tinggi kemampuan untuk menghasilkan laba bagi perusahaan. Kemampuan untuk menghasilkan laba dalam kegiatan operasi merupakan fokus utama dalam penilaian prestasi perusahaan. Laba menjadi indikator kemampuan perusahaan dalam memenuhi kewajiban kepada kreditur dan investor, serta merupakan bagian dalam proses penciptaan nilai perusahaan berkaitan dengan prospek perusahaan di masa depan. Return On Asset (ROA) dapat mengukur kemampuan perusahaan menghasilkan laba dengan menggunakan total aset yang dimiliki perusahaan setelah disesuaikan dengan biaya yang digunakan untuk mendanai aset tersebut seperti biaya pengembangan dan pengelolaan karyawan dalam meningkatkan

intellectual

(Rachmawati, 2012).

\section{Komite Audit}

Salah satu pilar dari corporate governance adalah komite audit. Komite audit sendiri merupakan suatu badan independen yang terdiri dari dewan komisaris tetapi tidak terlibat dalam kegiatan operasional perusahaan. Pada prinsipnya, tugas pokok dari komite audit adalah membantu dewan komisaris dalam melaksanakan pengawasan atas kinerja perusahaan (Fadhilah, 2014).

Berdasarkan Keputusan

Ketua Badan Pengawas Pasar Modal dan Lembaga Keuangan No: KEP643/BL/2012 Tentang Pembentukan dan pedoman pelaksanaan kerja komite audit, keanggotaan komie audit paling kurang terdiri dari 3 (tiga) orang anggota yang berasal dari Komisaris Independen dan Pihak dari luar Emiten atau Perusahaan Publik.

Keberadaan komite audit dalam suatu perusahaan berfungsi untuk membantu dewan komisaris dalam mengawasi pihak manajemen dalam menyusun laporan keuangan perusahaan dan melakukan pengawasan serta memberikan rekomendasi kepada manajemen dan dewan komisaris terhadap pengendalian yang telah berjalan sehingga dapat mencegah asimetri informasi (Diantari dan Ulupui, 2016).

\section{Leverage}

Leverage (struktur utang) merupakan rasio yang menunjukkan besarnya utang yang dimiliki oleh perusahaan untuk membiayai aktivitas operasinya. Penambahan jumlah utang akan mengakibatkan munculnya beban bunga yang harus dibayar oleh perusahaan. Komponen beban bunga akan mengurangi laba sebelum kena pajak perusahaan, sehingga beban pajak yang harus dibayar perusahaan akan menjadi berkurang (Adelina, 2012). Perusahaan besar lebih cenderung memanfaatkan sumber daya yang 
dimilikinya daripada menggunakan pembiayaan yang berasal dari utang. Perusahaan besar akan menjadi sorotan pemerintah, sehingga akan menimbulkan kecenderungan bagi para manajer perusahaan untuk berlaku agresif atau patuh (Maria dan Kurniasih, 2013).

\section{PENGEMBANGAN HIPOTESIS}

\section{Pengaruh Return On Assets terhadap Tax Avoidance}

Return On Assets (ROA) merupakan pengukur keuntungan bersih yang diperoleh dari penggunaan aktiva. Semakin tinggi rasio ini maka semakin baik produktivitas asset dalam memperoleh keuntungan bersih (Lestari dan Sugiharto, 2007). Menurut Kurniasih dan Sari (2013) Return on Assets (ROA) merupakan suatu indikator yang mencerminkan performa keuangan perusahaan, semakin tinggi nilai ROA, maka semakin bagus performa perusahaan. ROA berkaitan dengan laba bersih perusahaan dan pengenaan pajak penghasilan untuk wajib pajak badan. Secara logika, semakin tinggi nilai dari ROA, maka semakin tinggi profitabilitasnya. Jika profitabilitas perusahaan semakin tinggi, maka pajak yang dibayar akan semakin tinggi. Perusahaan yang memiliki profitabilitas tinggi memiliki kesempatan untuk melakukan tax avoidance yang mengurangi jumlah beban kewajiban perpajakan (Kurniasih dan Sari, 2013). Semakin tinggi penghindaran pajak yang dilakukan perusahaan semakin rendah tarif pajak suatu perusahaan. Hubungan antara ROA dijelaskan oleh teori agency, yang mana menyatakan bahwa manajer dengan rencana bonus akan berusaha untuk meningkatkan profitabilitas perusahaan, karena profitabilitas yang semakin tinggi akan meningkatkan bonus yang diterimanya (Hettihewa,2003). Berdasarkan uraian tersebut dapat dirumuskan kedalam hipotesis sebagai berikut:

H1: Return On Assets (ROA) berpengaruh negatif terhadapTax Avoidance.

\section{Pengaruh Komite Audit terhadap Tax Avoidance}

Forum For Corporate Governance in Indonesia (FCGI) menjelaskan tanggung jawab komite audit di bidang corporate governance adalah memberikan kepastian bahwa perusahaan tunduk pada undang-undang dan peraturan yang berlaku, dan mempertahankan kontrol yang efektif terhadap benturan kepentingan antara agen dan principal dalam menjalankan kontrak kerjasamanya (FCGI, 2002). komite audit merupakan organ dari dewan komisaris yang bertugas membantu dewan komisaris dalam pengawasan penyusunan laporan keuangan perusahaan. Semakin ketatnya pengawasan yang dilakukan pada suatu manajemen perusahaan maka akan menghasilkan suatu informasi yang berkualitas dan kinerja yang efektif (Hanum dan Zulaikha, 2013 dalam Diantari dan Ulupui 2016). 
Keputusan Ketua Badan Pengawas

Pasar Modal dan Lembaga

Keuangan No: KEP-643/BL/2012

Tentang Pembentukan dan pedoman pelaksanaan kerja komite audit, paling kurang terdiri dari 3 (tiga) orang anggota yang berasal dari Komisaris Independen dan Pihak dari luar Emiten atau Perusahaan Publik. Dengan lebih banyaknya anggota komite audit, maka diharapkan ada pengendalian internal yang lebih baik sehingga meningkatnya pengendalian kebijakan keuangan yang sangat ketat. Perusahaan yang memiliki komite audit akan lebih bertanggung jawab dan terbuka dalam menyajikan laporan keuangan karena komite audit akan memonitor segala kegiatan yang berlangsung di dalam perusahaan. Oleh sebab itu apabila peran komite audit benar-benar efektif maka akan mendorong pihak manajemen dalam hal melakukan perencanaan pajak akan sesuai dengan peraturan undang-undang pajak yang berlaku. Maharani dan Suardana (2014) menyatakan bahwa komite audit memiliki hubungan negatif dan signifikan terhadap tax avoidance, sedangkan pada penelitian Swingly dan Sukartha (2015) komite audit tidak berpengaruh terhdap tax avoidance. Dari penjelasan tersebut, maka hipotesis yang diajukan dalam penelitian ini adalah:

$\mathrm{H}_{2}$ : Komite Audit tidak berpengaruh terhadap Tax Avoidance.

\section{Pengaruh Leverage terhadap} Tax Avoidance

Leverage merupakan rasio yang digunakan untuk mengukur sejauhmana aset perusahaan dibiayai dengan utang. Artinya, berapa besar beban utang yang ditanggung perusahaan dibandingkan dengan asetnya. Perusahaan dimungkinkan menggunakan utang untuk memenuhi kebutuhan operasional dan investasi perusahaan. Akan tetapi, utang akan menimbulkan beban tetap (fixedrate of return) yang disebut dengan bunga. Beban bunga yang ditanggung perusahaan dapat dimanfaatkan sebagai pengurang penghasilan kena pajak perusahaan untuk menekan beban pajaknya. Dengan begitu bahwa semakin tinggi nilai dari rasio leverage, berarti semakin tinggi jumlah pendanaan dari utang pihak ketiga yang digunakan perusahaan dan semakin tinggi pula biaya bunga yang timbul dari utang tersebut. Biaya bunga yang semakin tinggi akan memberikan pengaruh berkurangnya beban pajak perusahaan. Semakin besar utang maka laba kena pajak akan menjadi lebih kecil karena insentif pajak atas bunga utang semakin besar, (Darmawan dan Sukartha, 2014). Hal tersebut membawa implikasi meningkatnya penggunaan utang oleh perusahaan (Prakosa, 2014).Hasil penelitian Supramono (2010) dan Sri Mulyani(2013) menunjukkan leverage berpengaruh terhadap penghindaran pajak. Berdasarkan uraian di atas dapat 
dirumuskan hipotesis sebagai berikut:

$\mathrm{H}_{3}$ : Leverage berpengaruh positif terhadap Tax Avoidance.

\section{METODE PENELITIAN}

\section{1) Populasi dan Sampel}

Populasi dalam penelitian ini adalah seluruh perusahaan jasa sub sector perdagangan besar barang produksi selama tahun 2012-2016. Metode penambilan sampel yang digunakan pada penelitian ini adalah purposive sampling yaitu suatu teknik dimana sampel yang akan dijadikan sebagai objek dalam penelitian adalah yang hanya memenuhi kriteri-kriteria yang telah ditentukan, berdasarkan pertimbangan-pertimbangan tertentu sesuai dengan tujuan penelitian (Sugiyono, 2014). Perusahaan jasa sub sector perdagangan besar barang produksi yang telah memenuhi kriteria sebagai sampel penelitian sebanyak 6 perusahaan selama 5 tahun penelitian, sehingga jumlah data yang digunakan pada penelitian ini sebanyak 30 data observasi.

\section{2) Definisi dan Pengukuran Variabel}

\section{a. Variabel Dependen}

Penghindaran pajak adalah usaha pengurangan pajak, namun tetap mematuhi ketentuan peraturan perpajakan seperti memanfaatkan pengecualian dan potongan yang diperkenankan maupun menunda pajak yang belum diatur dalam peraturan perpajakan yang berlaku (Heru,
1997 dalam Budiman dan Sutiyono 2012).

\section{b. Variabel Independen}

Menurut Sugiyono (2012:61), variabel independen disebut juga variabel bebas yang mempengaruhi atau yang menjadi sebab perubahan atau timbulnya variabel dependen. Variabel independen dalam penelitian ini adalah sebagai berikut:

\section{1) Variabel Dependen avoidance)}

Tax avoidance didefinisikan sebagai pengurangan utang pajak perusahaan. Penelitian ini memakai GAAP ETR untuk mengukur tax avoidance sesuai dengan Dyreng et al. (2008). effective tax rate dapat dihitung dari beban pajak dibagi dengan laba sebelum pajak dan tidak membedakan antara beban pajak kini dan beban pajak tangguhan sehingga dapat dirumuskan sebagai berikut:

ETR $=\frac{\text { Pembayaran Pajak }}{\text { Laba Sebelum Pajak }} \stackrel{X}{100 \%}$

2) Variabel Indepeden $X_{1}$ (Return on Assets)

Return on Assets adalah perbandingan antara laba bersih dengan total aset pada akhir periode, yang digunakan sebagai indikator kemampuan perusahaan dalam menghasilkan laba (Kurniasih dan Sari, 2013 dalam Andriyanto, 2015). ROA di ukur dengan rumus sebagai berikut:

$$
\text { ROA }=\frac{\text { Laba Bersih }}{\text { Total Asset }} \times 100 \%
$$


3) Variabel Indepeden $X_{2}$ (Komite Audit)

Proksi komite audit diukur dari jumlah komite audit dalam suatu perusahaan sesuai dengan aturan yang telah ditetapkan oleh BAPEPAM dan Kementrian BUMN mewajibkan komite audit minimal terdiri dari seorang ketua yang juga komisaris independen dan dua anggota eksternal independen (Hanum \& Zulaika, 2013). dirumuskan sebagai berikut:

Komite Audit $=\Sigma$ Anggota Komite Audit yang ada dalam perusahaan

\section{4) Variabel} (Leverage)

Proksi Leverage diukur dari rasio yang mengukur kemampuan utang, baik utang jangka panjang maupun utang jangka pendek yang digunakan untuk membiayai aktivitas perusahaan. Rasio leverage yang digunakan dalam penelitian ini adalah Debt to Assets Ratio (DAR).

Rumus untuk menghitung DAR adalah sebagai berikut:

DAR $=$ Total Kewajiban X 100\%

\section{TEKNIK ANALISIS DATA}

Analisis yang digunakan dalam penelitian ini adalah analisis regresi data panel (panel regression), yaitu dengan melihat pengaruh return on assets, komite audit, dan leverage terhadap penghindaran pajak pada perusahaan sub sektor perdagangan besar barang produksi. Adapun model regresi dalam penelitian ini adalah sebagai berikut:

$\mathrm{Y} i t=\alpha+\beta 1 \mathrm{X} 1 i t+\beta 2 \mathrm{X} 2 i t+\beta 3 \mathrm{X} 3 i t+$ $\beta \mathrm{nXnit}+$ eit

Keterangan :

$\mathrm{Y}=$ Tax Avoidance

$\alpha \quad=$ Konstanta

$\beta=$ Koefisien Regresi Variabel Independen

$\mathrm{X}_{1} \quad=$ Return On Assets

$\mathrm{X}_{2} \quad=$ Komite Audit

$\mathrm{X}_{3} \quad=$ Leverage

I $=$ Perusahaan

$t \quad=$ Waktu

$\varepsilon \quad=$ Eror Term

\section{Hasil dan Pembahasan}

1.Analisis Statistik Deskriptif

\begin{tabular}{|l|l|l|l|l|}
\hline & \multicolumn{1}{|c|}{ TA } & \multicolumn{1}{c|}{ ROA } & \multicolumn{1}{c|}{ KA } & LEV \\
\hline Mean & 25.70233 & 6.630667 & 3.200000 & 2.097333 \\
\hline Median & 25.75000 & 7.320000 & 3.000000 & 2.170000 \\
\hline Maximum & 35.61000 & 12.68000 & 4.000000 & 3.720000 \\
\hline Minimum & 14.55000 & 1.380000 & 3.000000 & 1.240000 \\
\hline Std. Dev. & 5.228182 & 2.920519 & 0.406838 & 0.660000 \\
\hline Skewness & 0.338304 & 0.222747 & 1.500000 & 0.349625 \\
\hline Kurtosis & 3.165956 & 2.58499 & 3.25 & 2.333021 \\
\hline Jarque-Bera & 0.606673 & 0.463372 & 11.32813 & 1.167265 \\
\hline Probability & 0.738350 & 0.793195 & 0.003468 & 0.557868 \\
\hline Sum & 771.0700 & 198.9200 & 96.00000 & 62.92000 \\
\hline Sum Sq. De & 792.6827 & 247.3536 & 4.800000 & 12.63239 \\
\hline Observations & 30 & 30 & 30 & 30 \\
\hline Sample: 2012 & 2016 & & & \\
\hline
\end{tabular}


Berdasarkan hasil output pengujian statistik deskriptif dengan Eviews, dapat diketahui bahwa jumlah sampel atau $\mathrm{N}$ dalam penelitian ini adalah 30 sampel. Sampel tersebut berasal dari 6 perusahaan dengan periode pengamatan selama 5 tahun yaitu dari tahun 2012-2016. Penjelasan untuk deskripsi masing-masing variabel dalam penelitian ini ialah sebagai berikut :

a.Mean adalah nilai rata-rat data, diperoleh dengan menjumlahkan seluruh data dan membaginya dengan cacah data (Winarno, 2015:39 dalam Eksandy dan Hakim, 2016). Mean terbesar dihasilkan oleh variabel TA 25.70233 sementara mean terkecil dihasilkan oleh variabel LEV yaitu sebesar 2.097333. Sementara mean dari variabel lainnya yaitu ROA sebesar 6.630667 dan KA sebesar 3.200000 .

b. Median adalah nilai tengah (rata-rata dua nilai tengah bila datanya genap) bila datanya diurutkan dari yang terkecil hingga yang terbesar (Winarno, 2015:39 dalam Eksandy dan Hakim, 2016). Median terbesar dihasilkan oleh variabel TA 25.75000 sementara median terkecil dihasilkan oleh variabel LEV yaitu sebesar 2.170000. Sementara mean dari variabel lainnya yaitu ROA sebesar 7.320000 dan KA sebesar 3.000000.

c. Maximum nilai paling besar dari data (Winarno, 2015:39 dalam Eksandy dan Hakim, 2016). Maximumn terbesar dihasilkan oleh variabel TA 35.61000 sementara maximum terkecil dihasilkan oleh variabel LEV yaitu sebesar 3.720000. Sementara maximum dari variabel lainnya yaitu ROA sebesar
12.68000 dan KA sebesar 4.000000 .

d. Minimum nilai paling kecil dari data (Winarno, 2015:39 dalam Eksandy dan Hakim, 2016). Minimum terbesar dihasilkan oleh variabel TA 14.55000 sementara minimum terkecil dihasilkan oleh variabel LEV yaitu sebesar 1.240000. Sementara minimum dari variabel lainnya yaitu ROA sebesar 1.380000 dan KA sebesar 3.000000 .

e. Standar deviasi adalah ukuran dispersi atau penyebaran data (Winarno, 2015:39 dalam Eksandy dan Hakim, 2016). Nilai standar deviasiterbesar dihasilkan oleh $\begin{array}{lll}\text { variabel } & \text { TA } & 5.228182\end{array}$ sementaranilai standar deviasi terkecil dihasilkan oleh variabel KA yaitu sebesar 0.406838. Sementara nilai standar deviasi dari variabel lainnya yaitu ROA sebesar 2.920519 dan LEV sebesar 0.660000 .

\section{Uji F}

$$
\begin{aligned}
& \text { Tabel 4.23 } \\
& \text { Hasil Uji F } \\
& \text { Perusahaan Jasa Sub Sektor Perdagangan Besar Barang Produksi } \\
& \text { Periode } 2012 \text { s/d } 2016 \\
& \text { Dependent Variable: TA } \\
& \text { Method: Panel Least Squares } \\
& \text { Date: 08/27/17 Time: 07:10 } \\
& \text { Sample: } 20122016 \\
& \text { Periods included: } 5 \\
& \text { Cross-sections included: } 6 \\
& \text { Total panel (balanced) observations: } 30 \\
& \begin{array}{llll}
\hline \text { F-statistic } & 7.619396 & \text { Durbin-Watson stat } 1.674414
\end{array} \\
& \text { Prob(F-statistic) } 0.000816 \\
& \text { Sumber: Data diolah EViews } 9.0
\end{aligned}
$$


sebesar 2.975154 dengan demikian $F$-statistic (7.619396) > F tabel (2.975154) dan nilai Prob(F-statistic) $0.000816<0,05$ maka $\mathrm{H}_{\mathrm{a}}$ diterima, maka dengan demikian dapat disimpulkan bahwa variabel independen dalam penelitian ini yang terdiri dari return on assets, komite audit, dan leverage secara bersamasama memiliki pengaruh terhadap praktik tax avoidance. Hal ini menunjukan model layak digunakan untuk menguji variabel independen pada variabel dependen.

\section{Uji Adjusted R-squared}

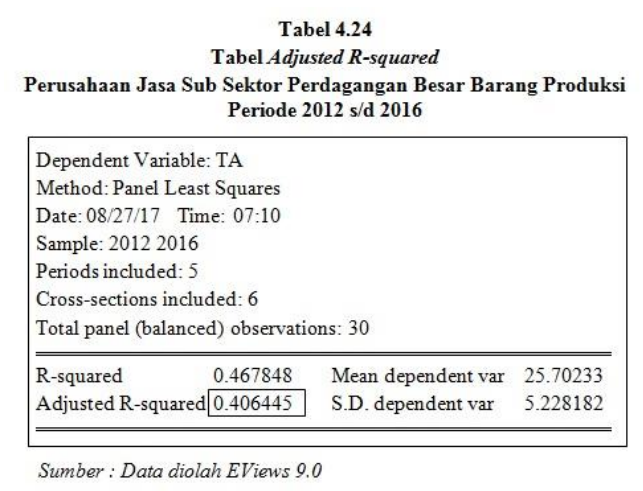

Berdasarkan tabel diatas, nilai Adjusted $R$-squared sama dengan 0.406445 yang berarti hanya $40.64 \%$ variabel bebas Return On Assets, Komite Audit, dan Leverage terhadap variabel terikat Tax Avoidance sedangkan sisanya sebesar $59.36 \%$ dijelaskan oleh faktor lain diluar model regresi.

\section{Uji Hipotesis Parsial (Uji t)}

\begin{tabular}{|c|c|c|c|c|}
\hline \multicolumn{5}{|c|}{$\begin{array}{l}\text { Dependent Variable: TA } \\
\text { Method: Panel Least Squares }\end{array}$} \\
\hline $\mathrm{C}$ & 45.19529 & 6.52325 & 6.928339 & 0 \\
\hline ROA & -0.876636 & 0.293564 & -2.986183 & 0.0061 \\
\hline KA & -4.753198 & 1.959475 & -2.42575 & 0.0225 \\
\hline LEV & 0.729481 & 1.231405 & 0.592397 & 0.5587 \\
\hline
\end{tabular}

1) Pengaruh Return On Assets Terhadap Tax Avoidance

Hipotesis pertama yang diajukan menyatakan bahwa return on assets (ROA) berpengaruh negatif terhadap tax avoidance. Hasil dari penelitian ini dapat diketahui bahwa variabel return on assets (ROA) memiliki $t$-statistic (2.986183) > $\mathrm{t}$ tabel (2.055529) dengan nilai signifikansi sebesar $(0.0061)<$ taraf signifikansi (0.05). Hasil tersebut menunjukkan bahwa return on assets berpengaruh terhadap tax avoidance, maka dapat disimpulkan bahwa hipotesis pertama $\left(\mathrm{H}_{1}\right)$ diterima.

\section{2) Pengaruh Komite Audit Terhadap Tax Avoidance}

Hipotesis kedua yang diajukan menyatakan bahwa komite audit tidak berpengaruh terhadap tax avoidance. Hasil dari penelitian ini dapat diketahui bahwa variabel komite audit memiliki t-statistic (2.425750) > $\mathrm{t}$ tabel (2.055529) dengan nilai signifikansi sebesar $(0.0225) \quad<$ taraf signifikansi (0.05). Hasil tersebut menunjukkan bahwa komite audit berpengaruh negatif terhadap tax avoidance, maka dapat disimpulkan bahwa hipotesis kedua $\left(\mathrm{H}_{2}\right)$ ditolak.

\section{3) Pengaruh Leverage Terhadap Tax Avoidance}

Hipotesis ketiga yang diajukan menyatakan bahwa leverage berpengaruh terhadap tax avoidance. Hasil dari penelitian ini dapat diketahui bahwa variabel leverage memiliki t-statistic 
$(0.592397)<\mathrm{t}$ tabel $(2.055529)$ dengan nilai signifikansi sebesar $(0.5587)>$ taraf signifikansi (0.05). Hasil tersebut menunjukkan bahwa leverage tidak berpengaruh terhadap tax avoidance, maka dapat disimpulkan bahwa hipotesis ketiga $\left(\mathrm{H}_{3}\right)$ ditolak.

\section{SIMPULAN}

Berdasarkan analisis data dalam pembahasan yang telah dilakukan, maka dapat diambil kesimpulan sebagai berikut :

1. Hasil analisis uji $\mathrm{t}$ menunjukkan bahwa variabel return on assets $\left(\mathrm{X}_{1}\right)$ berpengaruh negatif terhadap tax avoidance (Y). Hal ini ditunjukkan oleh nilai t-statistic (2.986183) > $\mathrm{t}$ tabel (2.055529) dengan nilai signifikansi sebesar $(0.0061)<$ taraf signifikansi (0.05) . Dapat dikatakan bahwa ada pengaruh yang positif antara return on assets pada tax avoidance. Hal ini dikarenkan semakin tinggi nilai dari ROA, berarti semakin tinggi nilai dari laba bersih perusahaan dan semakin tinggi profitabilitasnya. Perusahaan yang memiliki profitabilitas tinggi memiliki kesempatan untuk memposisikan diri dalam tax planning yang mengurangi jumlah beban kewajiban pajak nya.

2. Hasil analisis uji $\mathrm{t}$ menunjukkan bahwa variabel komite audit ( $\mathrm{x} 2)$ berpengaruh negatif terhadaptax avoidance (Y), ditunjukkan oleh $t$-statistic (2.425750) > $\mathrm{t}$ tabel (2.055529) dengan nilai signifikansi sebesar (0.0225) < taraf signifikansi (0.05). Hasil ini dikarenakan jika jumlah komite audit dalam perusahaan sudah sesuai dengan peraturan BEI, maka akan meminimalisasi tindakan manajemen dalam melakukan penghindaran pajak. Hasil analisis uji t menunjukkan bahwa variabel leverage ( $\left.\mathrm{x}_{3}\right)$ tidak berpengaruh terhadap tax avoidance (Y), ditunjukkan oleh nilai t-statistic $(0.592397)<\mathrm{t}$ tabel (2.055529) dengan nilai signifikansi sebesar $(0.5587)>$ taraf signifikansi (0.05). Hal ini dimungkinkan karena utang yang mengakibatkan munculnya beban bunga dapat menjadi pengurang laba pajak, sedangkan biaya bunga pinjaman bank tidak diperbolehkan sebagai beban pengurang penghasilan kena pajak sesuai dengan Surat Edaran Direktorat Jenderal Pajak Nomor 46/PJ.4/1995.

\section{REFRENSI}

Darmawan dan Sukartha, E-Jurnal Akuntansi Universitas Udayana. 9.1 (2014): 143-161 Issn: 2302-8556 Pengaruh Penerapan Corporate Governance, Leverage, Return On Assets, Dan Ukuran Perusahaan Pada Penghindaran Pajak Fakultas Ekonomi Dan Bisnis Universitas Udayana, Bali, Indonesia.

Darmawan Hendy dan Sukartha Made. 2014. E-Jurnal Akuntansi Universitas Udayana. Pengaruh Penerapan Corporate Governance, Leverage, Return On Assets, Dan Ukuran Perusahaan Pada Penghindaran Pajak, Fakultas Ekonomi dan 
Bisnis Universitas Udayana, Bali, Indonesia.

Eksandy.A dan Heriyanto. F, Modul Metode penelitian akuntansi dan keuangan (Analisis Regresi data panel dan regresi logistik data panel menggunakan program Eviews).

Maharani. 2015. Pengaruh Kualitas Auditor Eksternal Dan Komite Audit Terhadap Tax Avoidance (Studi Empiris Terhadap Perusahaan Yang Tercatat Di Indeks Kompas 100 Bursa Efek Indonesia Tahun 2010-2013), Skripsi Fakultas Ekonomi Universitas Diponegoro.

Musyarofah. E, 2016. Pengaruh Derivatif Keuangan, Leverage Dan Ukuran Perusahaan Terhadap Penghindaran Pajak (Studi Empiris Pada Perusahaan Non Keuangan Yang Terdaftar Di Bursa Efek Indonesia Periode 2012-2014), Universitas Islam Negeri Syarif Hidayatullah. Jakarta.

Nurfadilah, Mulyati Henny, Se.M.Com, Purnamasari Merry, Hastri Niar, Jurnal Issn 2460-0784 Pengaruh Leverage, Ukuran Perusahaan Dan Kualitas Audit,Terhadap Penghindaran Pajak (Studi Empiris Pada Perusahaan Manufaktur Yang TerdaftarDi Bursa Efek Indonesia Tahun 2011-2015) Resmi Siti, Perpajakan 2017, Edisi Sepuluh, Buku Satu. Jln.Raya Lenteng Agung No. 101: Salemba Empat.

Nurindah, 2013. Pengaruh Struktur Corporate Governance, Size, Profitabilitas Perusahaan Terhadap Tax Avoidance (Studi Pada Perusahaan Pertambangan Dan Manufaktur Yang Terdaftar Di Bursa Efek
Indonesia Tahun 2009-2011), Skripsi Fakultas Ekonomi Universitas Sebelas Maret. Surakarta.

Swingly Calvin dan Sukartha. 2015. E-Jurnal Akuntansi Universitas Udayana Pengaruh Karakter Eksekutif, Komite Audit, Ukuran Perusahaan, Leverage Dan Sales Growth Pada Tax Avoidance. Fakultas Ekonomi dan Bisnis Universitas Udayana, Bali, Indonesia.

Trisna Yudidan Suardana, E-Jurnal Akuntansi Universitas Udayana Vol.16.1. Juli (2016): 72-100 Pengaruh Proporsi Komisaris Independen, Komite Audit, Preferensi Risiko Eksekutif Dan Ukuran Perusahaan Pada Penghindaran Pajak Fakultas Ekonomi Dan Bisnis Universitas Udayana (Unud), Bali, Indonesia.

Tryaschasbian dan Martini Dwi. 2011. Pengaruh tax avoidance jangka panjang terhadap nilai perusahaan.

Yunika. 2015. Pengaruh Kualitas Audit, Komite Audit, Dan Komisaris Independen Terhadap Tax Avoidance. Skripsi Fakultas Ekonomi Dan Bisnis, Universitas Muhammadiyah Tangerang. 